\title{
Haloperidol-Induced Dyskinesias in the Monkey
}

\author{
P. BÉDARD, J. DELEAN. J. LAFLEUR AND L. LAROCHELLE
}

SUMMARY: Haloperidol $(0.25 \mathrm{mg} / \mathrm{kg}$ i.m.) "ras injected daily for 6 months in six normal monkeys. Over a 24 hour period. the following symptoms could be observed: akathisia, circling, akinesia, choreoathetoid and dystonic movements, oro-facial dyskinesias and postural tremor with or without harmaline. Six months after cessation of haloperidol, harmaline-indaced postaral tremor could still be observed in all animals and oro-facial abnormal movements, in one monkey. The nearopathologic study of the experimental material did not disclose any alteration of the central nervous system.

RÉSUMÉ: Dans la présente étude nous avons injecté de l'haloperidol $(0.25 \mathrm{mg} / \mathrm{kg}$ i.m.) quotidiennement pendant 6 mois, à six macaques normanx. Nous observions quotidiennement un ou plusieurs des symptomes suivants: akathisie, circling, akinésie, mowvements choréoathétoides et dystoniques, dyskinésies faciales, tremblement postural avec ou sans injection d'harmaline. 6 mois apres cessation du traitement à l'halopéridol. seule la dyskinésie faciale persistait spontanément chez $a n$ singe, mais l' harmaline qui normalement ne produit du tremblement que chez des animaux lésés, gardait son pouvoir trémorigène chez tous les animaux. L'étude histopathologique des cerveaux n'a révélé aucune anomalie.

From the Laboratoires de Neurobiologie, Québec, Canada.

Reprint requests to: $\mathrm{Dr}$. Paul Bédard, Laboratoires de Neurobiologie, Pavillon Notre-Dame, 2075 ave de Vitré, Québec, QUE., Canada G1J 5B3.

A preliminary report of this work has been given at the Meeting of the American Physiological Society, August 1972.

\section{INTRODUCTION}

With the more generalized use of neuroleptic drugs, attention has been drawn to the numerous extrapyramidal side-effects of these compounds (Ayd, 1961; Crane, 1968). Attempts have been made to understand the physiopathology of these phenomena on the basis of clinical experience and the histopathological examination of the brains of affected patients (Crane, 1968).

Although interesting changes have been reported from the histopathological study of the brains of patients affected with neurolepticinduced tardive dyskinesia, they are difficult to distinguish from those resulting from age or concurrent diseases.

For this reason it was thought desirable to check whether haloperidol, administered chronically, would lead to abnormal motor activity in unlesioned rhesus monkeys and to the production of histopathological changes. It was also thought that such drug-induced extrapyramidal disorders might prove useful models of other spontaneously occurring disorders such as chorea and athetosis.

Lesion-induced dyskinesias in the monkey have already yielded valuable information on the physiopathology of abnormal movements (Kennard, 1944; Carpenter et al., 1950; Poirier, 1960). More recently, drug-induced dyskinesias have been observed by many authors especially after large doses of L-DOPA (Battista et al., 1971; Mones, 1973; Paulson, 1973) or the chronic administration of chlorpromazine (Paulson, 1973; Deneau et al., 1969).

MATERIALS AND METHODS

Six normal monkeys (Macaca mulatta) weighing approximately
$4 \mathrm{~kg}$. were injected daily with haloperidol $0.25 \mathrm{mg} / \mathrm{kg} \mathrm{i.m}$. for six months.

A neurological examination was performed before the first injection, the axillary temperature was taken, and a cinematographic recording of the animals in their cage and in a restraining chair was made. Harmaline $(3 \mathrm{mg} / \mathrm{kg})$ was also injected. Harmaline is a reversible monoamine oxidase inhibitor that has the curious property of consistently inducing a postural Parkinsonian-like tremor only in animals with lesions involving specific structures of the central nervous system (Poirier et al., 1966; Larochelle et al., 1970). As expected, harmaline caused only a rapid non specific shivering and excitation in non lesioned monkeys.

The experiment lasted twelve months during which the same assessments were used periodically. These consisted of general observation of the behavior, a neurological examination, measurement of the weight, axillary temperature, testing the effect of harmaline and cinematographic recording. Electromyographic recording was also used to record certain pertinent motor phenomena.

After twelve months, the animals were sacrificed by an overdose of pentobarbital and their brains fixed in $10 \%$ formalin. Serial sections were prepared and stained with basic fuchsin and fast blue for histological examination.

\section{RESULTS (Table 1)}

All monkeys repeatedly displayed certain common features after each injection. Initially these consisted of excitation or restlessness, characterized by exploratory behavior and vocalizing and attempts to free themselves when sitting in a restrain- 
ing chair. This period usually lasted $30 \mathrm{~min}$. and was followed by a gradual decrease of motor activity leading to akinesia over a period of about $1 \mathrm{hr}$.

The akinesia lasted 10-12 hours during which the animals did not eat and drank very little. The next morning all monkeys appeared normal and calm. They had eaten their food and drunk their water.

There was no weight change during the first month of treatment, but in the next five months their weight increased, although at a slower rate than usual. Body temperature (axillary) remained stable in spite of the fact that they often exhibited shivering. The fur kept a healthy appearance throughout the experiment. Harmaline-induced tremor which was observed in all monkeys will be discussed later.

\section{PARTICULAR SIGNS}

In one animal $(\mathrm{H}-93)$, the initial excitement was associated with a stereotyped compulsive clockwise circling displayed every day in the half hour following the injection. As akinesia progressed, the circling gradually disappeared.

After the first month of treatment, we observed in monkey $\mathrm{H}-91$ abnormal movements that were par-

\section{TABLE 1}

Symptoms observed during a 24 -hour period following haloperidol $(0.25 \mathrm{mg} / \mathrm{kg}$ i.m.), 3 months after the beginning of treatment. Chewing movements in one monkey and harmaline-induced postural tremor in all six monkeys could be seen at any time. Numbers in brackets indicate the number of monkeys exhibiting the symptom.

Time after haloperidol

\begin{tabular}{|c|c|c|}
\hline $0-1 / 2 \mathrm{~h}$. & $\begin{array}{l}(6) \\
(6) \\
(1)\end{array}$ & $\begin{array}{l}\text { restlessness } \\
\text { akathisia } \\
\text { circling }\end{array}$ \\
\hline $1 / 2-1 \mathrm{~h}$. & $\begin{array}{l}(1) \\
(4)\end{array}$ & $\begin{array}{l}\text { progressive akinesia } \\
\text { postural tremor }\end{array}$ \\
\hline $1-6 \mathrm{~h}$. & $\begin{array}{l}(6) \\
(1)\end{array}$ & $\begin{array}{l}\text { deep akinesia } \\
\text { choreoathetoid and } \\
\text { dystonic movements }\end{array}$ \\
\hline $6-12 \mathrm{~h}$. & $\begin{array}{l}(6) \\
(4)\end{array}$ & $\begin{array}{l}\text { diminishing akinesia } \\
\text { postural tremor }\end{array}$ \\
\hline 12-24 h. & $\begin{array}{l}(6) \\
(1)\end{array}$ & $\begin{array}{l}\text { diminishing akinesia } \\
\text { postural tremor }\end{array}$ \\
\hline
\end{tabular}

ticularly conspicuous during the peak of akinesia, between 1 and 6 hrs, after the injection. First, there was rapid flexion and extension of the fingers, then torsion of the limbs and finally generalized dystonia involving the trunk and limbs. The latter signs appeared in several forms including crucifixion (Baruk et al., 1956) and walking with the head on the floor and the posterior limbs extended (Deneau et al., 1969). When the upper limbs were free, we observed repetitive movements of the fingers and hand reminiscent of athetosis (see film strip, fig. 1) and occasionally chewing and tongue protrusion. These abnormal movements were not abolished by DLalpha-methyl-tyrosine $(150 \mathrm{mg} / \mathrm{kg}$ i.p.) and they could not be triggered by apomorphine ( $1 \mathrm{mg} / \mathrm{kg}$ i.m.). All abnormal movements except those involving the oral region could be abolished by benztropine mesylate $(0.5 \mathrm{mg} / \mathrm{kg}$ i.m. $)$. Tremor, although diminished, was not completely abolished.

Monkey H-94 developed, after 2 months of treatment, rapid chewing movements and tongue protrusion. The movements were very similar to the tardive oral dyskinesias often described in human patients as a consequence of chronic neuroleptic treatment. They were not diminished 6 months after treatment with haloperidol had stopped. They were not modified either by DLalpha-methyl-tyrosine $(150 \mathrm{mg} / \mathrm{kg}$ i.p.) or by benztropine mesylate (0.5mg/kg i.m.).

In four animals, bursts of spontaneous Parkinsonian-like tremor of 4-8 cycles/sec. could be observed. They occurred after the peak akinesia had been reached, that is between 6-8 hours after the injection. They were more obvious in monkey H-91. They lasted 12 to 14 hours. In one animal tremor was first noted on the second day of treatment.

All monkeys reacted to harmaline $(3 \mathrm{mg} / \mathrm{kg}$ i.m.) by showing, after 15 minutes, a reproducible Parkinsonian-like tremor of the limbs and head. It was comparable to the tremor elicited by harmaline in monkeys with a cerebellar lesion. It could be observed on the first day of haloperidol treatment and at any time during treatment. Six months after withdrawal of haloperidol, when the behavior of the animals was almost indistinguishable from normal, harmaline $(3 \mathrm{mg} / \mathrm{kg}$ i.m.) would still elicit the same tremor in all monkeys that had received haloperidol chronically.

\section{MICROSCOPIC EXAMINATION}

No abnormal changes could be detected at the histological examination of the brains. In particular, the nuclei and pathways of the rubroolivo-cerebello-rubral loop appeared normal. The substantia nigra and other mesencephalic nuclei appeared normal even in the monkey with the orofacial dyskinesia. The striatum and pallidum also appeared normal.

In one brain we observed signs of cerebral vascular disease, namely a relatively old occlusion of the right anterior cerebral artery resulting in damage to the right gyrus cinguli and the corpus callosum. Other large arteries in the brain of this monkey also showed thickening and lesions of the endothelium. A thorough examination of the vessels in the brains of the other monkeys showed normal arteries.

\section{DISCUSSION}

The initial period of restlessness displayed by monkeys chronically receiving haloperidol could correspond to the akathisia observed in human patients. We could find no histological change in the brain of the monkey who showed circling during this period. Whether this ex-

Figure $l-8 \mathrm{~mm}$ film strip (18 frames/sec.) showing athetoid movements of the left hand in monkey $\mathrm{H}-91$ two hours after his daily dose of haloperidol $(0.25 \mathrm{mg} / \mathrm{kg}$ i.m. $)$, one month after the beginning of the experiment. Note successively from A to $\mathrm{H}$, fanning of the fingers, hyperextension and adduction of the fingers and supination of the hand. The animal was otherwise very akinetic. The sequence shown lasts approximately 0.5 second. 

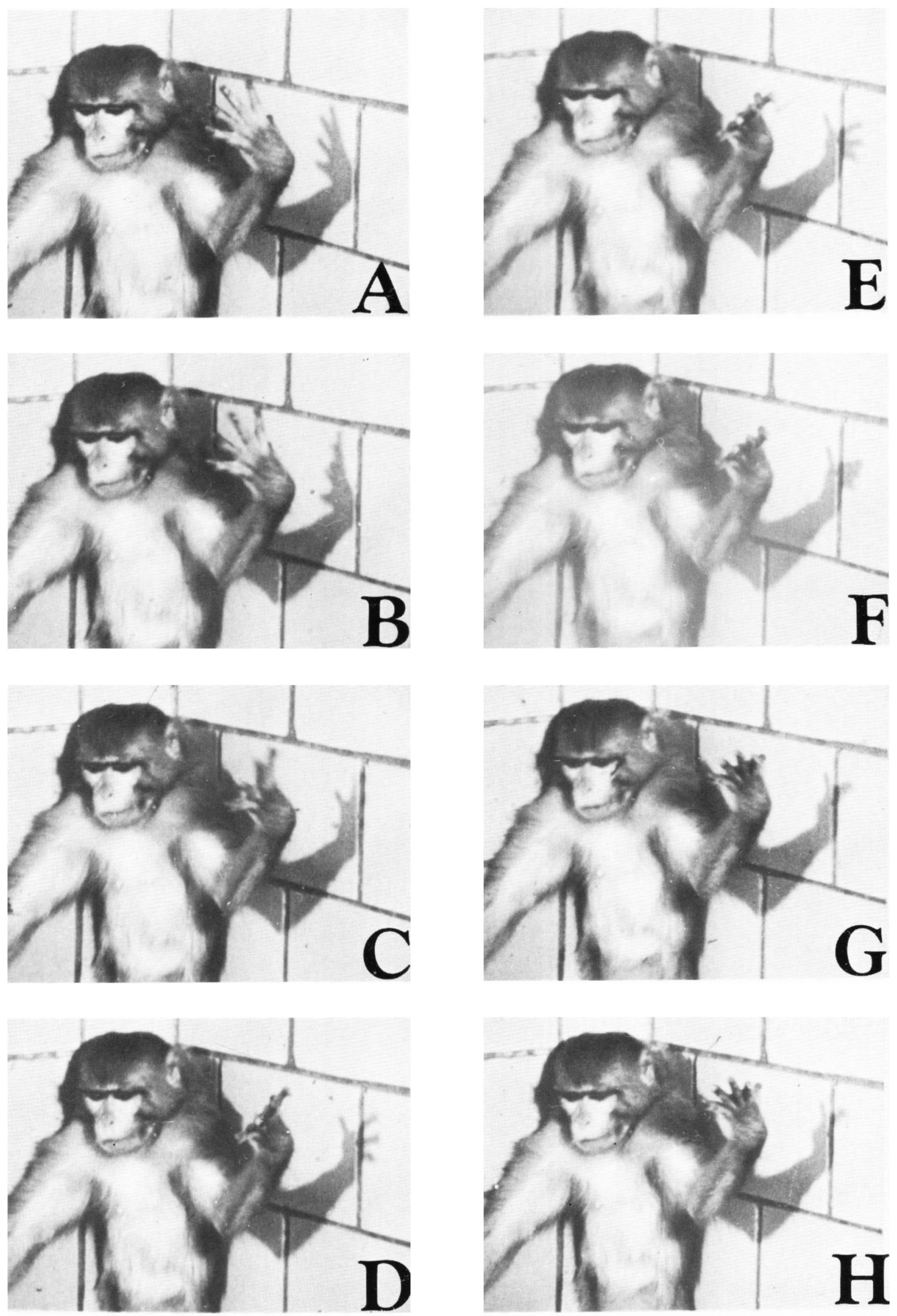
citement corresponds to an agonistic effect of haloperidol or to a transitory disinhibition is not clear.

The dystonic and choreo-athetoid movements seen in monkey $\mathrm{H}-91$ are clinically reminiscent of the acute dystonic symptoms seen in human patients following neuroleptic treatment (Ayd, 1961). They occurred during the peak of akinesia and usually replaced postural tremor. They were abolished by benztropine mesylate $(0.5 \mathrm{mg} / \mathrm{kg}$ i.m. $)$. Similar recurrent abnormal movements have been reported in the monkey after prolonged administration of chlorpromazine (Paulson, 1973; Deneau et al., 1969). In another study, the microscopic study of the brains of monkeys with such signs revealed possible morphological alterations of the astrocytes of the white matter (Cammermeyer, 1969). We could not find any significant morphological alteration in the brains of our monkeys.

The oral dyskinesia of monkey $\mathrm{H}-94$ is the only overt symptom that persisted for 6 months after cessation of haloperidol. Histological examination of the brain of this monkey revealed a normal substantia nigra and mesencephalic nuclei. Alterations of these cell groups have been reported in human patients presenting tardive dyskinesia (Christensen et al., 1970).

Akinesia resembling Parkinsonism was seen in all monkeys following the daily injections of haloperidol. Postural tremor ( $3-8$ cycles/sec.) was also present consistently in one monkey and occasionally in three others. Similar to our previous observations (Bédard et al., 1970; Larochelle et al., 1971), tremor is conspicuous before and after the peak of akinesia. During the akinetic period, the limbs appeared to be more rigid as assessed by passive mobilization.

Parkinsonian-like postural tremor has been ascribed to a combined involvement of the nigrostriatal dopaminergic pathway and of the corresponding neocerebellum and related brain stem structures (parvicellular red nucleus and inferior olivary nucleus) (Poirier et al., 1966; Larochelle et al., 1970; Poirier,
1970). Blockade of dopaminergic transmission is consistent with current theories on the mode of action of haloperidol (Janssen, 1967), but the drug must also induce a functional impairment of the neocerebellum and related brain stem structures. Selective accumulation of haloperidol has been detected by autoradiography in the cerebellum and especially in the Purkinje cells (Scarlato et al., 1967). This was confirmed biochemically by Janssen et al. (1968). It should also be remembered that there are noradrenergic pathways in the cerebellum (Hokfelt et al., 1969) that could be blocked by haloperidol.

Such impairment of the cerebellum is also necessary to explain the harmaline-induced tremor which has been observed only in connection with lesions of the neocerebellum and related structures. The presence of harmaline-induced tremor 6 months after withdrawal of haloperidol shows that this impairment is long lasting if not permanent. It has not been reported in humans since, without the harmaline test, it would have been undetected in our animals.

The cerebral vascular disease found in one monkey at the histological examination is probably a coincidental finding, but ought to be kept in mind should such pathology be reported in other studies.

\section{ACKNOWLEDGMENTS}

This work was supported by grants from the Medical Research Council of Canada.

We are indebted to Janssen Pharmaceutica, Beerse, Belgium, for a generous supply of haloperidol.

\section{REFERENCES}

AYD, F. J. (1961). A survey of drug-induced extrapyramidal reactions. JAMA: 175 , 1054-1060.

BARUK. H., LAUNAY, J. and BERGES, J. (1956). Physiologie psychiatrique expérimentale de la chlorpromazine chez les animaux et ses applications thérapeutiques chez l'homme. Encéphale: 45, 1258-1263.

BATTISTA, A. F., GOLDSTEIN, M. and OGAWA, M. (1971). Production of involuntary movements by L-DOPA in monkeys with tegmental lesions. Exp. Neurol.: $33,566-575$.
BEDARD, P., LAROCHELLE, L., POIRIER, L. J. and SOURKES, T, L. (1970). Reversible effect of L-DOPA on tremor and catatonia induced by a-methyl-p-tyrosine. Can. J. Physiol. Pharmacol.: 48, 82-84.

CAMMERMAYER, J. (1969). Neuropathological study of rhesus chronically treated with chlorpromazine, in A multidisciplinary workshop: Psychotropic drugs and dysfunctions of the basal ganglia. Washington, Public Health Service Publication No. 1938, pp 19-20.

CARPENTER, M. B., WHITTIER, J. R. and METTLER, F. A. (1950). Analysis of choreoid hyperkinesia in the rhesus monkey. J. Comp. Neur.: 92, 293-332.

CHRISTENSEN, E., MOLLER, J. E. and FAURBYE, A. (1970). Neuropathological investigation of 28 brains from patients with dyskinesia. Acta Psychiat. Scand.: 46. 14-23.

CRANE, G. E. (1968). Tardive dyskinesia in patients treated with major neuroleptics. A review of the literature. Amer. J. Psychiat.: 124 (suppl.) 40-48.

DENEAU, G. and CRANE, G. E. (1969). Dyskinesia in rhesus monkeys tested with high doses of chlorpromazine, in A multidisciplinary workshop: Psychotropic drugs and dysfunctions of the basal ganglia. Washington, Public Health Service Publication No. 1938, pp. 12-14.

HOKFELT, T. and FUXE, K. (1969). Cerebellar monoamine nerve terminals a new type of afferent fibers to the cortex cerebelli. Exp. Brain Res.: 9. 63-72.

JANSSEN, P. A. J. (1967). The pharmacology of haloperidol. Int. J. Neuropsychiat.: 3, $10-18$.

JANSSEN, P. A. J., SOUDIJN. W., VAN WIJNGAARDEN, 1 . and DRESSE. A. (1968). Pimozide: a chemically novel, highly potent and orally long-acting neuroleptic drug. Arzneimittel forschung.: 18, 280-287.

KENNARD, M. A. (1944). Experimental analysis of the functions of the basal ganglia in monkeys and chimpanzees. J. Neurophysiol.: 7, 127-148.

LAROCHELLE, L., BEDARD, P., BOUCHER, R. and POIRIER. L. J. (1970). The rubro-olivo-cerebello-rubral loop and postural tremor in the monkey. J. Neurol. Sci.: 11, 53-64.

LAROCHELLE, L., BEDARD, P., POIRIER, L. J. and SOURKES, T. L. (1971). Correlative neuroanatomical and neuropharmacological study of tremor and catatonia in the monkey. Neuropharmacol.: 10. 273-288.

MONES, R. J. (1973). Experimental dyskinesias in normal rhesus monkey. In: Barbeau, A., Chase, T. N. and Paulson, G. W. (Eds). Advances in Neurology, vol. 1. Huntington's Chorea, 1872-1972, Raven Press, New York, pp. 665-669.

PAULSON, G. W. (1973). Dyskinesias in monkeys. In: Barbeau, A., Chase. T. N. and Paulson, G. W. (Eds), Advances in 
Neurology, vol. 1, Huntington's Chorea 1872-1972. Raven Press, New York, pp. $647-650$.

POIRIER, L. J. (1960). Experimental and histological study of midbrain dyskinesia. J. Neurophysiol.: 23, 534-551.
POIRIER, L. J. (1970). Recent views on tremors and their treatment. In: Williams, D. (Ed), Modern trends in Neurology, vol. 5. Butterworths, London, pp. 80-95.

POIRIER, L. J., SOURKES, T. L., BOUVIER, G., BOUCHER, R. and
CARABIN, S. (1966). Striatal amines, experimental tremor and the effect of harmaline in the monkey. Brain: 89. 37-52.

SCARlato, G., PELligRINI, G. (1967).

Recherches sur la distribution dans le rat de

l'haloperidol marqué au tritium.

Psychopharmacologia: 11, 165-173. 